\title{
Forensic Accounting: Should It Be A Required Course For Accounting Majors?
}

J.W. Ted Ibex, (E-mail: Tlbex@rwcpas.com), CPA/ABVRosenfarb Winters Frank J. Grippo, (E-mail: grippof@wpunj.edu), William Paterson University

\begin{abstract}
Most of the general public and hopefully students of accounting are aware of the attention grabbing frauds of the $21^{\text {st }}$ Century, including Enron and Worldcom. Fraud and deceit are prevalent in our everyday lives, including activities of small business people when there are shareholder disputes and among individuals in matrimonial disputes. Forensic accountants are important to assist exposing the existence of fraud, but its role goes beyond dealing with fraud and includes applying investigative techniques to assist businesses and individuals to reveal the underlying financial facts or true value in various situations. Since Forensic Accounting is the fastest growing arena in the accounting profession, the authors believe that consideration should be given to its inclusion as a required course in the accounting curriculum.
\end{abstract}

\section{WHAT IS FORENSIC ACCOUNTING?}

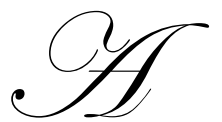

s stated in most dictionaries, forensic medicine is a science that deals with the relation of and application of medical facts to legal problems. Likewise, forensic accounting is a science (i.e. a department of systemized knowledge) that deals with the application of accounting facts gathered through auditing methods and procedures to legal problems. Forensic accounting is much different from traditional auditing. The main purpose of an audit is to examine the financial statements of an organization in order to express an opinion on the fairness of the financial statements. That is, auditors give an opinion as to whether the financial statements have been prepared in accordance with generally accepted accounting principles. Auditors employ limited procedures and use extensive testing and sampling techniques. An audit is not an investigation, and its main objective is not to uncover fraud. Audits are performed by independent accountants and are not conducted with a view to present the evidence in a judicial forum. On the other hand, forensic accounting is the investigation of an allegation with the idea in mind that the forensic accountant will have to present the evidence in a judicial forum. Forensic accountants often employ specialists in other areas as part of a team to gather evidence. In order to present the evidence in court, there must be absolute assurance. Thus testing and sampling methods are not employed as part of the evidence gathering procedures. The scope of the investigation is limited since it is determined by the client, but usually concerns issues relating to misappropriation of assets or fraudulent financial reporting. Forensic accounting thus is a specialty that is the integration of investigative, accounting and auditing skills. The forensic accountant looks at documents in a critical manner in order to draw conclusions and to calculate values. Forensic accountants review financial and other data to identify irregular patterns and/or suspicious transactions. Forensic accountants understand the fraud risk areas and have extensive fraud knowledge. Forensic accountants don't merely look at the numbers. They look behind the numbers. One can further say that forensic accounting is a discipline consisting of two areas of specialization, namely, litigation support specialists and investigation or fraud accountants. Litigation support specialists concern themselves with business valuation, testimony as expert witnesses, future earnings' evaluation and income and expense analysis. On the other hand, fraud accountants apply their skills to investigate areas of alleged criminal misconduct in order to support or dispel damages. In the opinion of the authors, these fields overlap such that a forensic accountant will do litigation support work one month and perhaps act as a fraud accountant on another engagement. Both of these engagements could result in expert testimony by the forensic accountant. Thus the authors prefer to define forensic accounting in a more generic way. 
It is merely a discipline where an individual utilizes his/her expertise in auditing, accounting and investigative skills to assist in disputes involving financial issues and data and in those cases where there is suspicion or allegation of fraud. The expertise of the forensic accountant may be used to support a plaintiff who is trying to establish a claim or to support a defendant in order to minimize the impact of a claim against him or her. Usually such investigations involve litigation. However, sometimes disputes are settled by negotiation. In either case, persuasive and authoritative evidence resulting from the financial and investigative skills of the forensic accountant is imperative. Therefore, the forensic accountant must be a good businessperson and be aware of statutory law, common law, and the laws of evidence and procedure. Usually the forensic accountant's findings are based on facts, not opinions. Facts can be investigated, and the forensic accountant can prepare a definitive report on the facts. Nevertheless, there are situations where the forensic accountant may rely on professional judgment and present findings using an opinion-type report. Needless to say, the reports based on facts usually do not present problems in court cases as they are supported by underlying documentation. Opinion reports, on the other hand, are subjective in nature and require that the forensic accountant demonstrates competency and provides adequate logic for his/her opinion. Two points are often overlooked when one is involved in a case as a forensic accountant. Namely, (1) the other side usually employs a forensic accountant as well; and (2) the credibility of a forensic accountant is extremely important. Thus the forensic accountant must have a high degree of professional standards and ethics.

\section{ARE FORENSIC ACCOUNTANTS NECESSARY?}

Business and criminal activities have become very complex such that lawyers and criminal investigators do not have the expertise necessary to discharge their responsibilities. This fact and the fact that there has been a marked increase in white-collar crime, marital and business disputes and other claims have created the need for a new industry called forensic accounting. Although as previously stated, forensic accountants are not only involved with fraud issues, the reality of the arena of forensic accounting is that most of the work does involve fraud investigations. In the case of fraud, the work of a forensic accounting team is crucial, as the business may not survive due to the fraud. Good business people must realize that fraud is a permanent risk in any and all businesses. Thus company leaders must devise ways to prevent fraud rather than trying to manage the consequences of fraud. Fraud has increased due to lack of government commitment, more sophisticated criminals, inefficiency of the judicial system, more complex technology, lack of adequate penalties and deterrence, and "old fashioned" greed and arrogance. Studies have shown that fraud will continue to increase. It is a well-known fact that most of the fraud results from employees, particularly high level employees. Other sources of fraud are customers, management, suppliers and service providers. In addition, the majority of the fraud is discovered as a result of strong internal controls. Other methods of discovery include whistle blowers, customers, internal auditors, by accident, or formal investigation. In the past, detecting so-called white-collar crime was deemed to be an accounting function caught either by the internal or external auditors through their periodic audits. However, we all know that the auditors' role is not to detect fraud and very little fraud is actually discovered by auditors. As stated previously, fraud established a new industry, not only for the person committing the fraud, but also for others-investigators, lawyers, and academicians. Therefore, we think that this raises the question as to whether the accounting curriculum in colleges and universities should include a required course in forensic accounting. One doesn't have to go back too far in history to appreciate the value that forensic accountants added to investigating fraud cases involving either malfeasance or financial reporting misstatements. One can certainly advance the argument that forensic accounting is a subset of auditing and its theory and practice should be taught as part of the auditing course. However, the authors maintain that although the disciplines are interrelated, auditing should be a pre-requisite for a course or courses in forensic accounting. We strongly believe that in one has to be a understand business to understand accounting. Likewise one must understand accounting to be a good auditor, and it follows that one must be a good auditor in order to be a good forensic accountant. Thus the purpose of the remainder of this paper is to support the argument that due to the complexity of the field of forensic accounting it deserves inclusion in the accounting curriculum as a stand-alone course, and further one that should be required as we believe it is no less important than studying taxes, cost, not for profit, or advanced accounting. 


\section{WHY EMPLOY A FORENSIC ACCOUNTANT?}

Clients retain forensic accountants when they are interested in either litigation support or investigations.

\section{Litigation Support}

This is a situation where the forensic accountant is asked to give an opinion on either facts that are known or those that are yet uncovered. The forensic accountant is an integral part of the legal team. In this capacity, he/she helps to substantiate allegations, analyze facts, dispute claims, and develop motives. The amount of involvement and point at which the forensic accountant gets involved, varies from case to case. Sometimes the forensic accountant is called upon from the beginning of the case; on the other hand, sometimes the forensic accountant may be called upon before the case is scheduled to go to court and after out of court settlements have failed. Thus in litigation support the forensic accountant assists in obtaining documentation to support or dispel a claim. He/she may be called upon to review documentation in order to give an assessment of the case to the legal team and/or identify area where a loss occurred. Moreover, the forensic accountant may be asked to get involved during the discovery stage to either help formulate questions or he/she may be asked to review the opposing expert's witness report and give an evaluation of its strengths and weaknesses. During trial the forensic accountant may serve as an expert witness, help to provide questions for cross-examination, and afterwards assist with settlement discussions.

\section{Investigations}

Investigations often involve fraud and are associated with criminal matters. Typically an investigative accounting assignment would result from a client's suspicion that there is employee fraud. Other parties, such as regulatory agencies, police forces and attorneys may retain a forensic accountant to investigate securities fraud, kickbacks, insurance fraud, money-laundering schemes, and asset search and analysis.

\section{HOW ARE LITIGATION AND INVESTIGATIVE SKILLS USED?}

A forensic accountant is used in a number of situations, including, but not limited to the following:

- $\quad$ Business Valuations - A forensic accountant evaluates the current value of a business for various personal or legal matters.

- $\quad$ Divorce Proceedings and Matrimonial Disputes - A forensic accountant may help to establish a realistic value, often with little or limited information, of the value of the couple's assets, particularly those associated with any businesses.

- $\quad$ Personal Injury and Fatal Accident Claims - A forensic accountant may help to establish lost earnings (i.e. those earnings that the plaintiff would have made except for the actions of the defendant) by gathering and analyzing a variety of information and then issue a report based on the outcome of the analyses

- $\quad$ Professional Negligence - A forensic accountant also helps to determine if a breach of professional ethics (e.g. failure to apply Generally Accepted Auditing Standards by a CPA when performing an audit) or other standards of professional practice has occurred. In addition, the forensic accountant helps to quantify the loss.

- Insurance Claims Evaluations - A forensic accountant may prepare financial analyses for an insurance company of claims, business income losses, expenses, and disability, liability or workmen's' compensation insurance losses.

- $\quad$ Arbitration - A forensic accountant is sometimes retained to assist with alternative dispute resolution (ADR) by acting as a mediator so that individuals and businesses can resolve disputes in a timely manner with a minimum of disruption.

- $\quad$ Partnership and Corporation Disputes - A forensic accountant may be asked to help settle disputes between partners or shareholders. Detailed analyses are often necessary of many records for a number of years. Most of these disputes relate to compensation and benefit issues. 
- $\quad$ Civil and Criminal Actions Concerning Fraud and Financial Irregularities - These investigations are usually performed by the forensic accountant for police forces. A report is prepared to assist the prosecutor's office.

- $\quad$ Fraud and White-Collar Crime Investigations - These types of investigations could be prepared for police forces as well or for businesses. Such investigations usually result from such activities as purchasing/kickback schemes, computer fraud, labor fraud, and falsification of inventory. The investigation by the forensic accountant often involves fund tracing, asset identification and recovery.

Thus it is apparent that the skill-set required of a forensic accountant cannot be taught in the traditional auditing course as one must understand the different ways fraud can be committed including revenue and expense recognition issues, skills such as investigative techniques, interviewing techniques, testifying skills, etc.

\section{STEPS EMPLOYED IN A TYPICAL FORENSIC ACCOUNTING ENGAGEMENT?}

Although each case is distinct and requires accounting and auditing procedures unique to the assignment, many forensic accounting assignments would, nevertheless, include the following steps:

- $\quad$ Arrange for a Meeting with the Client - The forensic accountant should meet with the client to determine the scope of the engagement. In addition, it is advisable to obtain an engagement letter specifying the terms of the engagement.

- $\quad$ Determine Independence - Just as CPAs should be independent when performing an audit or other attest services for clients, it is mandatory that the forensic accountant is independent. Otherwise, the credibility of the forensic accountant can easily be questioned if the engagement results in a legal case.

- $\quad$ Plan the Engagement - Prior proper planning is essential to any type of engagement. The plan should be similar to an audit program in that it should detail objectives and procedures in a form that addresses the scope of the engagement so that some type of conclusion can be reached.

- Gather Evidence and Perform Analyses - The forensic accountant should match his/her auditing, accounting or investigative techniques with the type of evidence that he/she is trying to obtain. A specific technique may satisfy more than one objective. When the forensic accountant, for example, performs an audit technique for a particular account, he/she also finds evidence for other accounts based on the double entry system of accounting. Forensic accountants use a variety of techniques including inquiry, confirmation, physical examination, observation, inspection, reconciliation, tracing, vouching, reperformance, and analytical procedures.

- $\quad$ Make Conclusion and Prepare the Report - The forensic accountant should write the final report in a manner that makes clear the nature of the assignment and scope of the work. It should indicate the approach used for discovery of information, and detail findings and/or opinions.

\section{SPECIFIC EXAMPLE}

A good example of the work of a forensic accountant is in the area of shareholder disputes, where fraud may or may not exist. Usually there is not fraud; rather there is merely a dispute concerning valuation of the stock.

What is meant by shareholder disputes? Since the authors are New Jersey CPAs, we will use the State of New Jersey as an example. New Jersey legislation defines oppression and provides protection to the oppressed minority shareholder in N.J.S.A. 14A:12-7. Where "in the case of a corporation having 25 or less shareholders, the directors of those in control have acted fraudulently or illegally, mismanaged the corporation, or abused their authority as officers and directors or have acted oppressively or unfairly toward one or more of the minority shareholders in their capacities as shareholders, directors, officers, or employees." N.J.S.A. 14A:12-7(1)(C).

The court has the authority to provide remedies for the shareholders claiming oppression in one of three ways: compel the sale of the minority interest, appoint provisional directors or custodians, or enter a judgment to dissolve the corporation. 
Examples of oppression are:

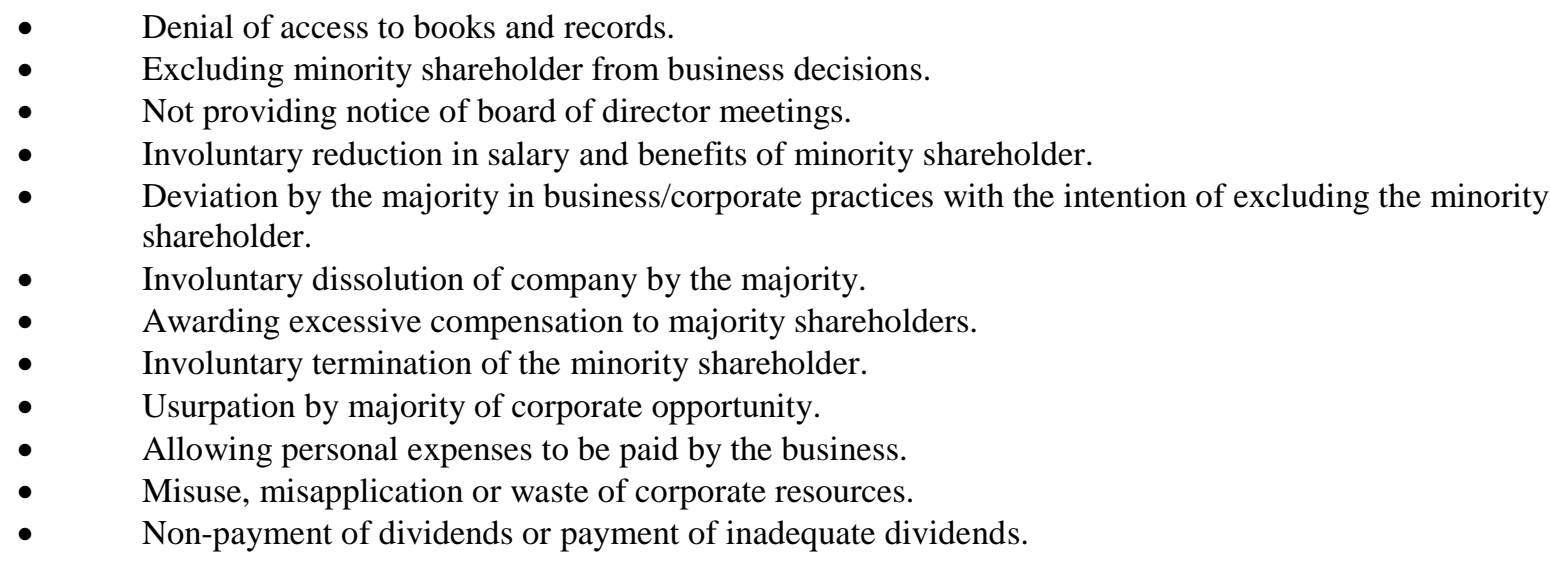

The list can be expanded. Think of situations where the majority take actions or set policy to the exclusion or detriment of the minority. Lawyers and forensic accountants in this business stress that the misconduct or oppression and the minority shareholder must be linked. That is to say that the minority shareholder must be damaged. It is pretty easy when the liberties of the majority lead to their enrichment to the exclusion of the minority. Excessive compensation and personal expenses translate into income that could have been used to pay dividends, or increase dividends. Other situations may be more difficult to quantify the damage. As long as the oppression and the minority shareholder can be related, the forensic accountant with the right skills can assist the oppressed and the oppressed attorney in identifying and quantifying damages.

It is the acts of oppression (discussed later) that lead to the claims by minority shareholders in closely held corporations that result in the services of forensic accountants to sort out the damages in monetary terms and to appraise the oppressed shareholders' ownership interest. Many times the business is a family business generations old. If it is not a family business, often times the shareholders were friends of many years standing. Although the role of the independent expert in these matters is to sort out the relevant facts, as well as to discover what the relevant facts are, as a human being you wonder how families and friendships led down a path and are torn apart over business disputes. Their disputes over money destroy relationships and families.

What skills does one need to bring to the table to assist the attorney and to help clients? Before one can be a good forensic accountant, one must be a good student of auditing. Likewise in order to be a good auditor, one must understand accounting and an understanding of business. "Business literacy" is an extremely important characteristic to have. Thus skills in accounting and auditing, taxation, business operations and management, internal controls, interpersonal relationships, and an understanding of psychology and people in general are necessary. In addition, communication is an important skill to possess. At the end of the day, communicating results into understandable reports to the client and attorney is the most important ingredient to success. If you cannot communicate, your knowledge and skills and their application are almost meaningless. Communications take many forms: written report, oral report, telephone conversations with various parties, giving testimony at deposition and trial, conference calls with the court, settlement conferences and so on. It is naïve to think that what we read in the papers about $21^{\text {st }}$ Century fraud and financial statement misrepresentation is something new. It is not. Rather these are merely variations of true-and-tried scams.

How do all of these skills and experience help those involved in oppressed shareholder litigation? The answers lie within the remedies available to the oppressed shareholder. From this article, one should see that the role and ability of the forensic accountant is to measure, quantify and appraise the financial implications and damages caused by the actions of the majority. In Sears Roebuck \& co, v. Camp it is said that equitable remedies "are distinguished for their flexibility, their unlimited variety, their adaptability to circumstances, and the natural rules which govern their use." The court has the power and the ability to devise a remedy to fit the circumstances. 
The broad power of the court extends beyond the oppressed shareholder statute to seek a remedy as decided in Walensky v. Jonathan Royce Int'l. Inc.

From our perspective, that says it all in terms of what the forensic accountant can be called upon to help. Working closely with counsel is essential in understanding the issues in a case. In our opinion the process of understanding begins with a thorough reading of the complaint and asking necessary questions to gain an understanding. It is here that the application of forensic skills can begin in offering suggestions on approaches to be taken and pointing out additional areas for forensic exploration that the lawyer has not considered. Teamwork is a variable in the success formula.

The remedies can very broad indeed. Remedies can involve buyout and valuation issues, the award of monetary damages, installing more effective accounting systems, changing the board of directors, appointing a fiscal agent or director to represent the oppressed shareholder, and many others. To ably assist the lawyer and client, the forensic skills needed are broad and far reaching as well.

Most of the problems that befall the minority shareholder are business related. Having something to do with how the business is operated or the decisions made by the managers of the business. Therefore having knowledge of how businesses operate and effective systems of internal controls and procedures is a must. Knowledge is both technical and practical. Spending years in auditing in public accounting provides an opportunity to achieve these experiences and develop skills that shape the forensic accountant in the future. In public accounting one sees every aspect of a business from the manufacturing floor, to the accounting department, to the boardroom. Along the way you meet, interview and interact with people throughout the corporation: workers, foremen, supervisors, managers, vice presidents, CFOs, CEOs, COOs, chairman of the board, chairman of the audit committee, and others. If one worked in public accounting, he/she has observed physical inventories, toured many offices and manufacturing facilities, discussed and solved many problems involving accounting, auditing and tax issues, written numerous reports on issues of internal control and recommendations for improvement, and finally prepared hundreds of financial statements and perhaps developed an expertise in a particular industry along the way. This is in authors' opinion is the best training before embarking on a career in forensic accountant. However, experience in private industry is useful as well as participating in the management of a business in a key capacity is a great experience. Being a CFO or having an important managerial position puts one's college education to practical use. Managing people, designing accounting systems, arranging bank financing, participating in budgeting and forecasting and developing strategic business plans, interacting with other executives and board of director members, and dealing with the day-to-day problems expands the base of knowledge that will only help the forensic accountant in the future. We believe that the private industry experience is a key component as well on the resume of a forensic accountant to communicate to the attorney who is thinking about engaging a forensic accountant.

A thorough understanding of business operations is important to being able to be of service. The general knowledge of business operations and the specific knowledge brought to the table can mean the difference in good service and outstanding service. Knowing were "to look" can help one get to the problem areas quickly and thus be able to provide timely, effective service. When the engagement requires forensic auditing, such skills become very important. This is particularly so when one is asked to quantify damages because the majority shareholders are looting the company through excessive salaries and benefits to the detriment of the minority shareholder because there is nothing left for dividends. Therefore, the forensic investigation is important to establish what the true income of the business is. What you see in the published income statement may paint the real picture of the earnings of the business. How do you value the business?

\section{Business Valuation Issues}

Often times, oppressed shareholder litigation requires the valuation of the equity of the business. There are a variety of possibilities here. The majority can be ordered to buy out the minority, the minority can be ordered to buy out the majority and the corporation can be ordered to buy out the shareholders. Business appraisal services are a science unto itself. To provide effective service in this area requires the forensic accountant to have additional education beyond the typical CPA training in business appraisal theory and science. Although most CPAs are well 
trained in accounting and auditing, we are not trained in business appraising, a specialized discipline. The accounting profession has in recent years developed a separate designation recognizing business appraisal as a specialized discipline. The designation Accredited Business Valuation (ABV) is awarded after passing a comprehensive examination. The $\mathrm{ABV}$ designation carries continuing educations requirements to maintain the designation.

In New Jersey we know that fair value is the standard of value to be used in oppressed shareholder litigation. The valuation date is generally as of the date of commencement of the litigation at hand. Much has been written about defining fair value as well as how to quantify it.

\section{What Is The Difference Between Fair Value And Fair Market Value?}

Ordinarily in determine the fair market value of a closely held corporation, and in particular a minority interest, the appraiser needs to consider discounts in the appraisal analysis for lack of control (often called or entitled discount for lack of control or minority interest discount) lack of marketability (often called or entitled discount for lack of marketability ) . Compared to a publicly traded company, a ready, available market is usually absent for the closely held corporation.

There have been many debates as to whether or not discounts are applicable. There is no simple "yes" or "no" here. There is no chart in a book to turn to for the answer. The driving influence is taking into account what is fair and equitable. New Jersey has dealt with the marketability discount in two 1999 decisions of the Supreme Court. They are Balsamides v. Protameen Chemicals, Inc. ("Balsamides") and Lawson Mardon Wheaton, Inc. v. Smith ("Lawson").

In Balsamides, the court concluded that it was fair and equitable to reflect a discount for lack of marketability`. The defendant oppressor in this case sold his shares to the oppressed shareholder. By not applying the discount, the court reasoned that the oppressor would have received an unwarranted bonus. A 35\% discount was applied in the Balsamides matter.

In Lawson, the corporation was to purchase shares of stock from dissenting shareholders to a proposed corporate reorganization. No discount was imposed because the Court held that non-marketability should only apply in extraordinary circumstances when the dissenting shareholder has exploited the transaction to divert value to the dissenting shareholder. Extraordinary circumstances were not found in Lawson. Another way to look it is that the corporation or majority shareholders would have benefited from the discount by enriching "the majority shareholder who may reap a windfall from the appraisal process by cashing out a dissenting shareholder...."

The well-informed forensic accountant can provide invaluable service with regard to business appraisal and the numerous issues that can and do arise. The existence of buy-sell agreements and purchase offers from third parties for example can impact the appraisal process and evaluation. For the forensic accountant of today, the education process does not stop. Business valuation is an evolving science. One must constantly be on the alert for new developments to continue to be an effective provider of service to the legal community.

\section{CONCLUSION}

None of the college training, experience in public accounting or private industry can completely prepare a forensic accountant for the variety of emotional levels that people in litigious situations display. It is one thing to meet and deal with people at their best, or nearly so, and it is quite another matter to deal with them when they are under stress. That is not to say that there is no stress in non-litigation situations, but this is quite different at times. With the substantial values that are usually involved in these matters, particularly matrimonial disputes, it is easy to understand how litigants can be very emotional on issues. Often some of the issues are trivial, but not to the litigants. 
When you are on the "wrong" side of a case, there is going to be someone that is going to be suspect of whatever the forensic accountant has to say about the value of a business or the extent of the impact of questionable activities. Of course, if you come up with the wrong "answers" for your client, your client may be upset with you as well. It is very important that forensic accountants be able to deal with people involved in emotionally charged situations. Only experience brings that ability. Experience linked with strong communication skills goes a long way in being able to be effective with a variety of people and their attitudes. Even in oppressed shareholder situations involving family members and long-time friends, emotions can be pretty elevated.

Furthermore, one's reputation and the attributes of independence and objectivity are extremely important. Being able to "think straight, talk straight" to people is a great attribute for a forensic accountant. At the end of the day, your next job is dependent on your last performance and your reputation. "Hired guns" in the forensic profession only serve to give dedicated, conscientious forensic accountants a hurdle to overcome. Eventually, independence, objectivity and sound work will be recognized. Can all of these skills discussed above be acquired in the typical college auditing course? We think not. The topic is much too important to exclude from the accounting curriculum.

\section{$\underline{\text { NOTES }}$}

